\title{
Private bankruptcy in the Russian Federation: reality and perspectives
}

\author{
Anatolii Nikolayevich Mironov ${ }^{*}$, Yulia Pavlovna Kolesnikova ${ }^{2}$, and Vladimir Mikhaylovich \\ Redkous $^{3}$ \\ ${ }^{1}$ Management Academy of the Ministry of Internal Affairs of Russia, Department of Management of \\ Public Security Forces of the Command Post Exercise Center, Moscow, Russia \\ ${ }^{2}$ Bankruptcy Expert Legal Center, Moscow, Russia \\ ${ }^{3}$ Institute of State and Law of the Russian Academy of Science, Sector of Administrative Law and \\ Administrative Process, Moscow, Russia
}

\begin{abstract}
The research is dedicated to a number of problematic areas in implementing a social function of individual bankruptcy. Crisis events of 2020 required measures from many states intended to support both large and small businesses and individual citizens. Personal bankruptcy as a legal tool provides an opportunity for persons with financial hardships to be legally released from further fulfillment of creditor claims. Along with that, it becomes more and more relevant to overcome bureaucratic, financial and other barriers to exercise rights and legal interests of consumers in this area. The paper is intended to identify a number of problems impeding the implementation of the social function of private bankruptcy and to develop possible solutions during the discussion. These issues were addressed based on regulatory and scientific sources containing relevant information on the institute of private bankruptcy using a number of general scientific (analysis, induction) and particular scientific (formally legal) methods. The research resulted in a list of primary problematic aspects in legal regulation and practice of private bankruptcy in the Russian Federation impeding the implementation of the social function of this institute. Solutions are proposed for discussion, which are related to financing private bankruptcy, abuse of the creditor right, low level of population awareness of the ways, methods and consequences of solving issues connected with overdue debts. This paper presents an overview of primary problematic aspects and their solutions. Each aspect will be considered in more detail in future researches. Keywords: bankruptcy, individual bankruptcy, insolvency, private bankruptcy
\end{abstract}

\section{Introduction}

Substantial changes in social communications, both intranational and international, have inevitably resulted in crisis events destructively affecting large corporations, individual households and citizens in most countries of the world.

\footnotetext{
${ }^{*}$ Corresponding author: mironov.ufa@mail.ru
} 
Private bankruptcy is an important tool of any capitalistic society that ensures a balance of interests of debtors and creditors, reduces social strain and brings back active consumers of material assets to the market. The current growth of actual private bankruptcies in most countries has caused a need to review individual legal provisions and revealed existing problems in the practice of implementing such provisions, in the area of moral and ethical substantiation of the procedure, in the area of legal awareness of the population of basics of private financial activity. These circumstances compelled the scientific society to identify and present urgent issues and to form proposals that would be able to contribute to overcoming economic crisis events.

During the research, we used various theoretical surveys of domestic and foreign colleagues. Special attention should be paid to the research of the law professor in the Illinois University in Chicago, Kilborn [1] dedicated to the financing of private bankruptcy procedures in Russia. Issues of financing the bankruptcy procedure and solving the issues of such financing for the socially vulnerable population are considered in the paper by Ramsay [2].

Studying the problems of private bankruptcy in Russia resulted in the need to analyze similar and different models of personal bankruptcy in various states. The American and continental models of private bankruptcy are discussed in detail in the paper of the Hungarian researcher Walter [3].

Issues of abuse of rights, moral responsibility and moral risks of debtors related to private bankruptcy are discussed in the scientific project of scientists from the Brigham Young University and the Massachusetts Institute of Technology [4].

In terms of issues of insufficient legal awareness of the population in the area of bankruptcy, development of rumors and surmises around the modern Russian law on private bankruptcy, theoretical conclusions were based on taking into account theoretical positions of Skvortsova and Yaroshenko [5]. Interesting opinions concerning the effects of social surroundings on the upcoming bankruptcy procedure, its perspectives and release from financial burden are described in the paper by Kleiner, Stoffman, Yonker [6]. In the paper, we were also based on the conclusions obtained by Malaysian researchers about the role of creditors in the prediction of potential bankruptcies of creditors [7].

In terms of the dependence of dynamics of individual bankruptcies, theoretical value is shown by a scientific paper developed by researchers of large American universities and dedicated to the analysis of Covid-19 effects on the practice of bankruptcy in general [8] as well as researches that evaluated the role of employers and corporative policy in dynamics of individual bankruptcies [9].

Relevant Russian materials that become the basis of our research are the papers by Kasatkina, Barinov, Kuznetsova [10], Kozlova [11], Shaykhutdinov [12], Nazarov [13], Kulazhnikov [14], etc.

This paper considers, in a comprehensive way, a number of regulatory issues that impede implementation of the social function of individual bankruptcy that is especially relevant taking into account economic stagnation and current crisis events. Hypothesis: individual problems of legal regulation of social relationships occurring in the area of private bankruptcy that had an insignificant effect on legal practice before crisis 2020 now require resolution within a number of measures that must be included in the system of state anticrisis measures.

The paper is intended to identify a number of problems impeding the implementation of the social function of private bankruptcy and to develop possible solutions during the discussion.

The research is intended to identify specific problems and formulate ways to solve them in the following areas: financing the procedure of individual bankruptcy; extrajudicial private 
bankruptcy; rumors and surmises around bankruptcy legislation impending implementation of citizen rights; abuse of the creditor and debtor right.

\section{Methods}

These issues were addressed based on regulatory and scientific sources containing relevant information concerning the institute of private bankruptcy. Criteria for selecting sources were relevance and adaptivity of their content to the period of the 2020 crisis. The main hypothesis was confirmed by studies of monographic narrow-field researches of foreign and domestic experts.

Taking into account the scope of problematic issues that must be discussed within the topic under study, the authors of this article confined themselves to overviewing the primary problem and improvement areas of law and practice. Specific aspects will be considered in more detail in future researches.

\section{Results}

Table 1. Problems and solutions.

\begin{tabular}{|l|ll|}
\hline \multicolumn{1}{|c|}{ Problem } & \multicolumn{1}{c|}{ Solution } \\
\hline $\begin{array}{l}\text { 1. Financing the } \\
\text { individual bankruptcy } \\
\text { procedure }\end{array}$ & $\bullet \begin{array}{l}\text { An opportunity of using resources of the bankrupt estate provided } \\
\text { there is property to be sold; } \\
\text { Development of bankruptcy of individual households (families) in } \\
\text { order to save legal expenses and other mandatory expenses; } \\
\text { Development of the institute of extrajudicial bankruptcy; } \\
\text { Integration of foreign experience in the development of the } \\
\text { institute of private trustees. }\end{array}$ \\
\hline $\begin{array}{l}\text { 2. Abuse of the right by } \\
\text { creditors }\end{array}$ & $\bullet \begin{array}{l}\text { Combating aggressive credit marketing (reactions of the Federal } \\
\text { Anti-Monopoly Service, Federal Supervision Agency for Customer } \\
\text { Protection and Human Welfare, etc.); }\end{array}$ \\
\hline $\begin{array}{l}\text { 3evelopment of the institute of due diligence applicable to the } \\
\text { evaluation of financial solvency of a potential borrower by the } \\
\text { promoting the abuse of } \\
\text { the right by the debtor } \\
\text { and impeding exercising } \\
\text { of its right }\end{array}$ & $\begin{array}{l}\text { creditor. } \\
\text { Organization of legal informing and education of citizens, namely, } \\
\text { by creating informational resources, hotlines, etc.; } \\
\text { Stimulation of private education projects implemented based on } \\
\text { various informational resources. }\end{array}$ \\
\hline
\end{tabular}

\section{Discussion}

Problems of financing individual bankruptcies are raised by most domestic and foreign authors. Problems of financing are the main barriers to implementing a social function of this legal institute: those who need to be released from further fulfillment of creditor claims usually don't have financial resources to cover all expenses. Currently, compulsory expenses for the procedure that include payment of court-appointed manager services, publication in specific sources exceed forty thousand Rubles in the Russian practice of individual bankruptcies. Moreover, the practice shows that the procedure of individual bankruptcy belongs to expert procedures and requires legal support.

When analyzing expert literature, one can encounter various proposals intended to alleviate the debtor burden related with financing individual bankruptcy. For example, there are proposals to use resources of municipal budgets to fund bankruptcy procedures for 
individual categories of citizens [15], on development of the institute of private trustees (sponsors) of the debtor [1], etc. We have summarized some proposals in the table and we find it reasonable to open a discussion to reveal the most perspective of them taking into account specifics of the Russian legal practice. We also believe that in current conditions the solution for this problem can be achieved by facilitating access to extrajudicial bankruptcy and by developing a bankruptcy mechanism for households (families) using digitization opportunities.

In the perspective aspect, it is important to develop the institute of responsible attitude of the creditor to loaning. In case of failure to comply with obligations, the creditor is the party whose interests are violated. However, in the conditions of low financial literacy of the population, the practice of aggressive marketing of credit products leads to a high level of debt load of some participants of social relations. Here, we should note already achieved positive steps from the state limiting opportunities of individual micro-financial organizations to issue loans against the security of immovable property and with an unlimited interest rate. Along with that, we believe that the sphere of consumer loans lacks a doctrine of due diligence of the creditor similar to the sphere of tax legal matters. The latter indicates an obligation of the subject of taxation to exert due diligence when selecting a counter party. The fact that the creditor has not exerted due diligence when granting a loan must be taken into account by courts when taking a decision on releasing the debtor from fulfilling obligations in disputes concerning individual bankruptcies.

As stated above, there is a low level of awareness of those citizens who need to be released from further fulfillment of creditor's claims. Informational uncertainty in the field of personal insolvency is typical of the most stable systems of personal bankruptcy. For example, Fisher notes that in the USA the issue of who must apply for bankruptcy is not unambiguous [16].

The practice of legal consultation allowed identifying groups of issues in the field of individual bankruptcy that are covered by informational uncertainty: who can apply for judicial and extra-judicial bankruptcy (rumors concern the debt, overdue debt, pledged assets, etc.)?; what are circumstances of personal bankruptcy (consequences are either underestimated or too overestimated)?; will I be criminally liable or liable in any other legal way for bankruptcy? will restrictions be implied to the bankrupt parental rights?, etc. Insufficiency of legal awareness of the population, namely in the area of legal regulation of financial insolvency is a general problem impeding the implementation of various rights and legal interests of the Russian population. But the development of private informational projects implemented based on social networks and video-hostings significantly facilitates this problem. State authorities only have to stimulate high-quality private informational legal projects. Any form of state stimulation will allow such a project to increase a confidence level and advantages against sources with a low educational aspect or containing disinformation.

\section{Conclusion}

Overview of problems impeding the implementation of the social function of private bankruptcy and their solutions can be deemed completed. Each of the covered aspects must be specified by individual researches and proposed conclusions can obtain a reaction from colleagues that will be taken into account by the authors during further studies of this matter.

\section{References}

1. J.J. Kilborn, Am. Bankruptcy Law J. (2019) http://dx.doi.org/10.2139/ssrn.3491945 (forthcoming) 
2. I.A. Ramsay, International Insolvency Review, 29(S1), S4-S24 (2020) https://doi.org/10.1002/iir.1357

3. G. Walter, Personal Bankruptcy: Model structures and the fresh start, in Corvinus Economics Working Papers, 2020/02 Corvinus Univ. Budapest (2020)

4. B. Argyle, B. Iverson, T. Nadauld, C. Palmer, Running up the Tab: Personal Bankruptcy, Moral Hazard, and Shadow Debt (2020). Accessed on: March 17, 2021. [Online]. Available:

https://www.fdic.gov/bank/analytical/cfr/consumer/2020/argyle.pdf

5. T.A. Skvortsov, D.A. Yaroshenko, Colloq.-J. 7(59) (2020)

6. K. Kleiner, N. Stoffman, S.E. Yonker, J. Fin. Econ. 139(2), 578-605 (2021) https://doi.org/10.1016/j.jfineco.2020.08.003

7. S.H. Syed Nor, S. Ismail, B.W. Yap, J. Ec., Finance and Ad. Sc. 24(47), 157-170 (2019). https://doi.org/10.1108/JEFAS-08-2018-0076

8. J. Wang, J. Yang, R. Kluender, B. Iverson, Bankruptcy and the COVID-19 Crisis (2020). Accessed on: March 17, 2021. [Online]. Available: http://www.beniverson.org/papers.html

9. Y. Chen, J. Halford, H. Hsu, C. Lin, J. Fin. and Quantitative Anal. 55(7), 2397-2428 (2020). https://doi.org/10.1017/S0022109019000620

10. E.A. Kasatkina, A.V. Barinov, I.A. Kuznetsova, Hum. Soc-Ec. and Soc. Sc. 3 (2020)

11. V.V. Kozlova, Herald of Omsk State Univ. Ser. Law. 3, 103-108 (2020)

12. E.M. Shaikhutdinov, Rel. Iss. Rus. Law 10(119), 65-71 (2020)

13. D.G. Nazarov, Eurasian Advocacy, 1(32), $42-44$ (2018)

14. V.V. Kulazhnikov, Soc.: Politics, Ec., Law 11(64), (2018). https://doi.org/10.24158/pep.2018.11.17

15. D.Yu. Grishmanovsky, L.V. Sotnikova, Vestnik South-Ural State Univ. Ser. Law 1, 33-40 (2019)

16. J.D. Fisher, J. Consumer Affairs 53(4), 2003-2026 (2019) https://doi.org/10.1111/joca.12280 